\title{
Elucidation of Unexpectedly Weak Catalytic Effect of Doping with Cobalt of the Cryptomelane and Birnessite Systems Active in Soot Combustion
}

\author{
Piotr Legutko ${ }^{1}$ Jacek Pęza ${ }^{1}$ Alvaro Villar Rossi ${ }^{1,2}$ - Mateusz Marzec ${ }^{3} \cdot$ Tomasz Jakubek $^{1} \cdot$ Marcin Kozieł $^{1}$. \\ Andrzej Adamski ${ }^{1}$
}

Published online: 20 February 2019

(c) The Author(s) 2019

\begin{abstract}
In this work the influence of cobalt doping on both properties and catalytic activity of cryptomelane and birnessite in soot combustion was investigated in detail. The investigated samples have been synthesized by a microwave-assisted hydrothermal method and cobalt was introduced in two ways-by impregnation or by addition to the precursor mixture before hydrothermal treatment. The obtained catalysts have been characterized by XRF, BET, XRD, RS, XPS and ATR-IR. Surprisingly, no distinct effect of cobalt presence on catalytic activity has been found. Most probably cobalt was localized in the position of manganese within the cryptomelane/birnessite structure or within segregated manganese-cobalt complex oxides, where its oxidation level was fixed. A series of reference manganese-cobalt mixed oxides (100-0\% Mn) have been synthesized to elucidate this effect. These samples have been structurally characterized and thermal evolution of their structures was profoundly investigated. A high tendency of cobalt incorporation into the manganese oxide matrix and its subsequent stabilization in the spinel forms was proposed as an explanation of the observed lack of a promotional effect of this additive in soot combustion.
\end{abstract}

Keywords Cryptomelane $\cdot$ Birnessite $\cdot$ Cobalt doping $\cdot$ Soot combustion $\cdot$ Structural evolution

\section{Introduction}

All possible serious environmental (i.e. undesired contribution to global climate change, negative influence on plant growth, deposition on snow and ice resulting in a reduced ability to reflect sunlight, uncontrolled participation in carbon and impurities circulation cycles in natural ecosystems) and health problems (i.e. cardiovascular, nervous and respiratory problems, perturbations of fetal development, mutagenic changes) caused by vehicular emission led to the introduction of many strict regulations like Euro 6, Beijing 6/VI LD/HD and China 6 LD, Light-Duty (LD)

Piotr Legutko

piotr.legutko@uj.edu.pl

1 Faculty of Chemistry, Jagiellonian University, Gronostajowa 2, 30-387 Kraków, Poland

2 Chemical Engineering Department, University of Alicante, PO box 99, 03080 Alicante, Spain

3 Academic Center for Materials and Nanotechnology, AGH-UST, Av. Mickiewicza 30, 30-059 Kraków, Poland
Real-Driving Emissions (RDE) NOx, US Phase 2 HD greenhouse gas, Indian Bharat 6/VI or California $\mathrm{HD} \mathrm{NO}_{\mathrm{x}}$ program [1]. These regulations forced further development of minimal- or zero-emission technologies. In the case of $\mathrm{CO}_{2}$ reduction the engine efficiency was improved, while new catalysts for selective catalytic reduction (SCR) were developed to decrease $\mathrm{NO}_{\mathrm{x}}$ emissions [1]. In the case of solid particulate emissions, which are among the most toxic components emitted by various engines, both fundamental and applied studies were focused on particulate filters. While filtering technology for diesel engines (DPF) has recently been strongly advanced, it is still a relatively new field for gasoline engines (GPF). The relevance of GPF is increasing due to the introduction of more and more strict regulations (i.e. PM emission for diesel-powered vehicles changed from $0.14 \mathrm{~g} / \mathrm{km}$ for EURO 1 to $0.005 \mathrm{~g} / \mathrm{km}$ for EURO 6, while EURO 5 introduced emission standards for gasoline-powered vehicles at a level of $0.005 \mathrm{~g} / \mathrm{km}$ ). One of the newest ideas in the field of car emission abatement introduced by BASF is a so called 4-way catalyst for gasoline-powered vehicles, which may be considered as a combination of a 3-way catalyst applied for simultaneous removal of $\mathrm{NO}_{\mathrm{x}}$, 
unburned hydrocarbons and $\mathrm{CO}$, with a dedicated gasoline particulate filter [1]. The most important problem of DPF/ GPF usage is their efficient regeneration and one of the most promising solutions is the use of a catalyst, which shifts the combustion window into lower temperatures [2].

A variety of catalysts have been investigated for soot combustion, some of them have been classified by D. Fino as: (i) ceria-based catalyst; (ii) perovskite/spinel/hydrotalicte/ delafossite catalysts; (iii) other metal/mixed metal oxides [3] or more detailed after A. Bueno-Lopez as: (i) platinum catalysts, (ii) non-platinum noble metals and silver catalysts, (iii) perovskite catalysts, (iv) spinel catalysts, (v) ceria catalysts, (vi) metal chlorides, (vii) molten salts, (viii) alkaline metal catalysts [4]. In particular the last group seems to be the most promising because of satisfactory activity and for economic reasons [5, 6]. As both soot and a catalyst are in a solid state, therefore the physical contact between them is key for a satisfactory catalytic activity in soot combustion. Regarding this particular aspect, it was confirmed that the activity of catalysts containing potassium was substantially improved due to the presence of mobile $\mathrm{KO}_{\mathrm{x}}$ species [7, 8]. Other possible mechanisms is the formation of low-meltingpoint compounds, like $\mathrm{KNO}_{3}$, which also improve physical contact between soot and the catalyst [9]. The main problem with alkali metals is the efficient control of their mobility, which is a crucial factor in the case of catalytic activity but simultaneously it can also be problematic from the viewpoint of catalyst stability $[7,10]$. One of the possible solutions to avoid uncontrollable loss of alkalies is the stabilization of a given alkali metal within a transition metal oxide structure [7, 10]. A good example of compounds which meet such requirements can be iron oxides doped with potassium stabilized inside of tunnels and/or between oxometallic layers-monoferrite $\mathrm{KFeO}_{2}$ and $\beta$-ferrite $\mathrm{K}_{2} \mathrm{Fe}_{22} \mathrm{O}_{34}[11,12]$, layered cobaltates $\mathrm{K}_{\mathrm{x}} \mathrm{CoO}_{2}[12,13]$ or potassium-manganese oxides: tunneled cryptomelane $\mathrm{KMn}_{8} \mathrm{O}_{16}$ and layered birnessite $\mathrm{KMn}_{4} \mathrm{O}_{8}$ [12, 14-16]. They were investigated in the case of soot combustion, exhibiting high activity in this reaction with the last group deserving particular attention $[7,9,10$, 17-19].

A tailored and optimized doping is a powerful technique to control the properties of a catalyst, likewise in the case of transition metal oxides with potassium stabilized within their matrices [20]. In the case of potassium, the related processes, including, migration, segregation and desorption of this component, strongly depends on the presence of alioelectronic additives as demonstrated in the case of potassium ferrites: $s(\mathrm{Mg}), p(\mathrm{Al}), d(\mathrm{Cr}, \mathrm{Mn})$ and $f(\mathrm{Ce})[20,21]$. Moreover, it was found in [22] that transition-metal-doping of cryptomelane increased the surface area of the final system as well as the concentration of oxygen vacancies and surface-bonded $\mathrm{OH}$ groups, which resulted in a substantial increment of catalytic activity in the oxidation reactions. The application of vanadium-doped cryptomelane in soot combustion was also investigated [19] and a significant enhancement of catalytic activity was observed mainly due to a more tight soot-catalyst contact.

As reported by Jinzhu Ma et al. [23], cryptomelane can be successfully doped with cobalt by a hydrothermal method, however its consequent activity in ozone decomposition was lower than that of the parent catalyst. Cobalt was introduced to cryptomelane also by microwave synthesis by L. R. Pahalagedara et al. [24] and a significant increment of its activity in selective oxidation of benzyl alcohol to benzyl aldehyde was observed. Cobalt-doping of birnessite by addition of $\mathrm{CoCl}_{2}$ to a boiling solution of $\mathrm{KMnO}_{4}$ was reported by Hui Yin et al. in the context of non-catalytic environmental applications [25].

Despite several reports on higher activity of cobalt-doped manganese systems in catalytic soot abatement, compared to that observed for the corresponding undoped manganese oxides, the promotion of cryptomelane and birnessite with cobalt has not been studied in detail in the context of total carbon oxidation $[6,12,15]$. The main goal of our work was thus to investigate in more detail how cobalt-doping can influence the catalytic activity of such Mn-based systems in soot combustion and to understand the behavior of the doped catalysts. In our case both cryptomelane and birnessite were promoted with cobalt in two routes (impregnation and addition to precursor mixture before the reaction) and in two concentration levels ( 5 and $12 \mathrm{~mol} \%$ of Co). The synthesized samples have been characterized in detail and their catalytic activity in soot combustion was tested in laboratory scale (loose contact) using a Degussa-PrintexU model soot. Moreover, the reference samples of manganese-cobalt mixed oxides $(0-100 \% \mathrm{Mn})$ were synthesized and their structure has been characterized for better understanding of the results obtained for the Co-doped cryptomelane and birnessite samples.

\section{Experimental}

\subsection{Synthesis of Catalysts and Reference Samples}

Synthesis of birnessite $\mathrm{KMn}_{4} \mathrm{O}_{8}$ and cryptomelane $\mathrm{KMn}_{8} \mathrm{O}_{16}$ was developed on the basis of the procedure described in [26]. A reference birnessite (bir_ref) sample was synthesized by the following route: $90 \mathrm{mg}$ of $\mathrm{KMnO}_{4}$ and $70 \mathrm{mg}$ of $\mathrm{KNO}_{2}$ were separately dissolved in $57 \mathrm{ml}$ of distilled water, each. After dissolving both precursors, the solutions were mixed. The $\mathrm{pH}$ value of the final mixture was close to 9 . The obtained precursor solution was subsequently placed in a Teflon-lined microwave-assisted Ertec autoclave and treated at $170{ }^{\circ} \mathrm{C}$ under 36 bar for $20 \mathrm{~min}$. In the next step, the obtained precipitates were separated by centrifugation, 
washed several times with distilled water and dried in air at $60{ }^{\circ} \mathrm{C}$ for $48 \mathrm{~h}$. A reference cryptomelane (cryp_ref) sample was synthesized in the similar way-the only difference was adjusting $\mathrm{pH}$ of the mixture before hydrothermal treatment to 3 by adding $0.5 \mathrm{M}$ solution of sulfuric acid. Due to relatively small amount of the catalysts obtained in the first series a synthesis modification was adopted. Concentrations of the initial solutions of both potassium permanganate and potassium nitrate(III) were doubled. The birnessite and cryptomelane samples obtained by the modified method were called bir_mod and cryp_mod, respectively. The labels of all investigated samples are collected in Table 1.

Cobalt doping was achieved by two methods: addition of cobalt(II) nitrate(V) to the mixture of precursors before hydrothermal treatment and dry impregnation of the obtained samples by a cobalt(II) nitrate(V) aqueous solution. In the first case, to obtain the samples containing 5 (bir_5Co and cryp_5Co) or $12 \mathrm{~mol} \%$ cobalt (bir_12Co and cryp_12Co), 16.57 or $41.45 \mathrm{mg}$ of cobalt(II) nitrate(V)

Table 1 Descriptions of the investigated samples with corresponding codes

\begin{tabular}{|c|c|}
\hline Sample & Code \\
\hline \multicolumn{2}{|l|}{ Birnessite } \\
\hline Method based on literature & bir_ref \\
\hline Synthesis modified by concentration doubling & bir_mod \\
\hline $5 \mathrm{~mol} \%$ Co-doping of precursor mixture & bir_5Co \\
\hline $12 \mathrm{~mol} \%$ Co-doping of precursor mixture & bir_12Co \\
\hline 5 mol\% Co impregnation & bir_5Co_imp \\
\hline $12 \mathrm{~mol} \%$ Co impregnation & bir_12Co_imp \\
\hline \multicolumn{2}{|l|}{ Cryptomelane } \\
\hline Method based on literature & cryp_ref \\
\hline Synthesis modified by concentration doubling & cryp_mod \\
\hline $5 \mathrm{~mol} \%$ Co-doping of precursor mixture & cryp_5Co \\
\hline $12 \mathrm{~mol} \%$ Co-doping of precursor mixture & cryp_12Co \\
\hline 5 mol\% Co impregnation & cryp_5Co_imp \\
\hline $12 \mathrm{~mol} \%$ Co impregnation & cryp_12Co_imp \\
\hline \multicolumn{2}{|l|}{ Reference samples } \\
\hline $100 \% \mathrm{Mn}-0 \% \mathrm{Co}$, calcined at $430^{\circ} \mathrm{C}$ for $3 \mathrm{~h}$ & $100 \mathrm{Mn}-430$ \\
\hline $75 \% \mathrm{Mn}-25 \% \mathrm{Co}$, calcined at $430^{\circ} \mathrm{C}$ for $3 \mathrm{~h}$ & $75 \mathrm{Mn}-430$ \\
\hline $50 \% \mathrm{Mn}-50 \% \mathrm{Co}$, calcined at $430{ }^{\circ} \mathrm{C}$ for $3 \mathrm{~h}$ & $50 \mathrm{Mn}-430$ \\
\hline $25 \% \mathrm{Mn}-75 \% \mathrm{Co}$, calcined at $430{ }^{\circ} \mathrm{C}$ for $3 \mathrm{~h}$ & $25 \mathrm{Mn}-430$ \\
\hline $0 \% \mathrm{Mn}-100 \% \mathrm{Co}$, calcined at $430{ }^{\circ} \mathrm{C}$ for $3 \mathrm{~h}$ & $0 \mathrm{Mn}-430$ \\
\hline $100 \% \mathrm{Mn}-0 \% \mathrm{Co}$, calcined at $980^{\circ} \mathrm{C}$ for $6 \mathrm{~h}$ & $100 \mathrm{Mn}-980$ \\
\hline $75 \% \mathrm{Mn}-25 \% \mathrm{Co}$, calcined at $980^{\circ} \mathrm{C}$ for $6 \mathrm{~h}$ & $75 \mathrm{Mn}-980$ \\
\hline $50 \% \mathrm{Mn}-50 \% \mathrm{Co}$, calcined at $980^{\circ} \mathrm{C}$ for $6 \mathrm{~h}$ & $50 \mathrm{Mn}-980$ \\
\hline $25 \% \mathrm{Mn}-75 \% \mathrm{Co}$, calcined at $980^{\circ} \mathrm{C}$ for $6 \mathrm{~h}$ & $25 \mathrm{Mn}-980$ \\
\hline $0 \% \mathrm{Mn}-100 \% \mathrm{Co}$, calcined at $980{ }^{\circ} \mathrm{C}$ for $6 \mathrm{~h}$ & $0 \mathrm{Mn}-980$ \\
\hline $100 \% \mathrm{Mn}$ impregnated with $0.5 \mathrm{~mol} \% \mathrm{Co}^{2+}{ }_{\mathrm{aq}}$ & $0.5 \mathrm{Co}-\mathrm{Mn}$ \\
\hline $100 \% \mathrm{Mn}$ impregnated with $1 \mathrm{~mol} \% \mathrm{Co}^{2+}$ & $1 \mathrm{Co}-\mathrm{Mn}$ \\
\hline $100 \% \mathrm{Mn}$ impregnated with $3 \mathrm{~mol} \% \mathrm{Co}^{2+}{ }_{\mathrm{aq}}$ & 3Co-Mn \\
\hline
\end{tabular}

hexahydrate were added to the initial mixture, respectively. In turn, in the second case, the proper amounts of cobalt precursor were dissolved in a minimal amount of distilled water and added to the samples (bir_5Co_imp, bir_12Co_ imp, cryp_5Co_imp and cryp_12Co_imp).

Additionally, reference samples have been synthesized. The samples of molar compositions: $100 \% \mathrm{Mn}(100 \mathrm{Mn}-$ 430), $75 \% \mathrm{Mn}-25 \% \mathrm{Co}$ (75Mn-430), 50\% Mn-50\% Co (50Mn430), 25\% Mn-75\% Co (25Mn-430) and 100\% Co (0Mn-430) were coprecipited from water solutions of manganese(II) and cobalt(II) nitrates(V) with an $0.8 \mathrm{M}$ ammonium carbonate solution. The obtained precipitates were dried overnight and then calcined at $430{ }^{\circ} \mathrm{C}$ for $3 \mathrm{~h}$. The samples with the same molar compositions have been synthesized and calcined at $980{ }^{\circ} \mathrm{C}$ at $6 \mathrm{~h}$, giving samples named $100 \mathrm{Mn}-980,75 \mathrm{Mn}-$ 980, 50Mn-980, 25Mn-980 and Mn-980. Moreover, a sample containing $100 \%$ of Mn was impregnated with cobalt(II) nitrate $(\mathrm{V})$ solution to achieve $0.5(0.5 \mathrm{Co}-\mathrm{Mn}), 1(1 \mathrm{Co}-\mathrm{Mn})$ and $3 \mathrm{~mol} \%$ of cobalt $(3 \mathrm{Co}-\mathrm{Mn})$.

\subsection{Characterization of the Investigated Catalysts and Reference Samples}

Chemical composition of the synthesized samples was determined by means of an energy-dispersive X-ray fluorescence (XRF) spectrometer (Thermo Scientific, ARL QUANT'X). The X-ray radiation was generated with a $\mathrm{Rh}$ anode (4-50 kV with $1 \mathrm{kV}$ step). $1 \mathrm{~mm}$ size beam and a $3.5 \mathrm{~mm} \mathrm{Si}(\mathrm{Li})$ drifted crystal detector with a Peltier cooling $\sim 185 \mathrm{~K}$ were used. For the quantitative analysis, a UniQuant software along with a series of the calibration metallic standards was applied.

$\mathrm{X}$-ray diffractograms (XRD) were collected for all investigated samples with using a Panalytical X'pert Pro diffractometer equipped with a PW3050/60 goniometer and $\mathrm{Cu}_{\mathrm{K} \alpha}$ lamp $(\lambda=1.5406 \AA)$. Anode voltage and anode current values were set to $40 \mathrm{kV}$ and $30 \mathrm{~mA}$, respectively. The diffraction patterns were collected in the range of $2 \Theta$ angles $10-90^{\circ}$ with a step of $0.026^{\circ}$.

The micro-Raman spectra were recorded under ambient conditions using a Renishaw InVia spectrometer equipped with a Leica DMLM confocal microscope and a CCD detector, with an excitation wavelength of $785 \mathrm{~nm}$. The laser power at the sample position was $1.5 \mathrm{~mW}(0.5 \%$ of total power) with a magnification of 20 times. The Raman scattered light was collected in the spectral range of $150-800 \mathrm{~cm}^{-1}$. At least $9 \mathrm{scans}, 15 \mathrm{~s}$ each, were accumulated to ensure a sufficient signal to noise ratio.

The specific surface area was determined by $\mathrm{N}_{2}$ adsorption at $-196{ }^{\circ} \mathrm{C}$ using a 3Flex (Micromeritics) automated gas adsorption system. Prior to the analysis, the samples were outgassed under vacuum at $350{ }^{\circ} \mathrm{C}$ for $24 \mathrm{~h}$. Values were determined using the BET equation. For birnessite 
obtained values ranged from 125 to $300 \mathrm{~m}^{2} / \mathrm{g}$ and for cryptomelane from 70 to $115 \mathrm{~m}^{2} / \mathrm{g}$.

The X-ray photoelectron spectroscopy (XPS) analyses were carried out in a PHI VersaProbeII Scanning XPS system using monochromatic $\mathrm{Al} \mathrm{K}_{\alpha}(1486.6 \mathrm{eV}) \mathrm{X}$-rays focused to a $100 \mu \mathrm{m}$ spot and scanned over the sample area of $400 \mu \mathrm{m} \times 400 \mu \mathrm{m}$. The photoelectron take-off angle was $45^{\circ}$ and the pass energy in the analyzer was set to $23.50 \mathrm{eV}$ to obtain high energy resolution spectra for the $\mathrm{C} 1 \mathrm{~s}, \mathrm{O} 1 \mathrm{~s}$, $\mathrm{K} 2 \mathrm{p}, \mathrm{Mn} 2 \mathrm{p}$ and Co $2 \mathrm{p}$ regions. A dual beam charge compensation with $7 \mathrm{eV} \mathrm{Ar}^{+}$ions and $1 \mathrm{eV}$ electrons were used to maintain a constant sample surface potential regardless of the sample conductivity. All XPS spectra were charge referenced to the unfunctionalized, saturated carbon (C-C) $\mathrm{C} 1 \mathrm{~s}$ peak at $284.8 \mathrm{eV}$. The operating pressure in the analytical chamber was lower than $4 \times 10^{-9}$ mbar. Deconvolution of the spectra was carried out using $P H I$ MultiPak software (v.9.7.0.1) with embedded relative sensitivity factors for each element. Spectrum background was subtracted with using the Shirley method.

Attenuated Total Reflectance-Infrared spectroscopy (ATR-IR) measurements were carried on ThermoScientific Nicolet iS5 spectrometer equipped with iD3 ATR with ZnSe crystal device. The spectra were collected in the frequency range of 4000-650 $\mathrm{cm}^{-1}$ with a resolution of $4 \mathrm{~cm}^{-1}$. In order to obtain a satisfactory intensity, each spectrum was measured accumulated 64 times.

\subsection{Catalytic Tests}

The activity of the synthesized catalysts in soot combustion was determined by means of TPO (temperature-programmed oxidation). The quartz fixed-bed reactor was heated $\left(10^{\circ} \mathrm{C} /\right.$ min) from RT to $750{ }^{\circ} \mathrm{C}$ while the concentrations of the released gases were measured by a quadrupole mass spectrometer (SRS RGA 200). Gas composition was 3.3\% $\mathrm{O}_{2}$ and $0.3 \% \mathrm{NO}$ in He at $60 \mathrm{ml} / \mathrm{min}$ flow. The samples for the combustion test have been prepared by weighing $0.005 \mathrm{~g}$ of soot (Degussa-PrintexU) and the catalyst with a soot/catalyst 1:10 ratio and then gently mixed in an Eppendorf tube following the loose contact protocol. Repeatability of the adopted method was investigated earlier for cryptomelane and birnessite samples and the results differed from each other no more than $15-25^{\circ} \mathrm{C}$.

\section{Results and Discussion}

\subsection{Structural Properties and Catalytic Behavior of Cryptomelane and Birnessite}

All investigated samples of undoped and Co-doped cryptomelane and birnessite were active in catalytic soot combustion and the observed temperature windows of soot combusion on both birnessite and cryptomelane remain in good agreement with results of previous studies found in the literature for powders [7, 9, 10], supported catalysts [17] and monoliths [27]. However, the addition of up to $12 \mathrm{~mol} \%$ of cobalt to both birnessite and cryptomelane did not lead to any substantial changes in their catalytic activity in soot combustion as can be seen in Fig. 1. In the case of birnessite, the activity of impregnated samples (bir_5Co_imp and bir_12Co_imp) differed from those determined for the other investigated catalysts. The corresponding conversion curves have been shifted to higher temperatures $\left(\Delta T_{50}=30-45^{\circ} \mathrm{C}\right)$, revealing the lower activity of these samples. Unexpectedly, the observed shift did not increase with higher cobalt concentration. The remaining samples of birnessite series did not differ in their catalytic performance, showing $T_{50}$ in the range $440-455{ }^{\circ} \mathrm{C}$. In the case of cryptomelane all determined $T_{50}$ values were observed in the range of $465-490{ }^{\circ} \mathrm{C}$. Taking into account the repeatability of this method $\left(15-25{ }^{\circ} \mathrm{C}\right)$, it can be stated that no promotional effect of cobalt can be observed. This observation was quite surprising, because doping with cobalt has been reported in [28] as an effective method of boosting activity of cryptomelane in the electrocatalytic oxygen evolution reaction.

The first interpretation of our experimental results reported above can be adopted basing on structural data presented in Fig. 2, showing powder diffraction patterns of the synthesized catalysts. As it can be seen in Fig. 2Aa-d only the characteristic reflections attributed to birnessite can be observed (PDF code 01-082-2727). Contrary to this, Fig. 2Ae-f displays also additional reflections at $c a$. $18,28.7,31,31.9,36.2,44.7$ and $47.9^{\circ}$, attributable to $\mathrm{Mn}_{2.42} \mathrm{Co}_{0.58} \mathrm{O}_{2}$ (PDF code 04-018-1863). The formation of the $\mathrm{Mn}_{2.42} \mathrm{Co}_{0.58} \mathrm{O}_{2}$ phase, being a manganese-cobalt oxide of spinel structure, can be responsible for the activity decrement observed for these two samples. Such an interpretation was based on the fact, that undoped manganese and cobalt single oxides are not very active in soot combustion, as $\mathrm{M}-\mathrm{O}$ (where $\mathrm{M}=\mathrm{Co}, \mathrm{Mn}$ ) bond strengths in the corresponding oxides are too high to make oxidation of carbon possible, as it was shown in $[29,30]$. In turn, promotion with potassium can modify the $\mathrm{M}-\mathrm{O}$ bond strengths in the case of manganese and cobalt oxides of spinel structures [31], which can result in higher activity. In this case no promotional effect was observed, therefore the interaction between cobalt and potassium can be excluded. In the case of the cryptomelane series (Fig. 2B) only the typical reflections, which have been attributed to $\mathrm{KMn}_{8} \mathrm{O}_{16}$, can be observed (PDF code 00-044-0141). In both cases of cryptomelane and birnessite, the oxidation states of manganese were mainly $\mathrm{Mn}^{4+}$ and $\mathrm{Mn}^{3+}$ with the ratio depending on the amount of potassium (positive charge of potassium must be neutralized by a partial reduction of $\mathrm{Mn}^{4+}$ to $\mathrm{Mn}^{3+}$ ). Basic structural 


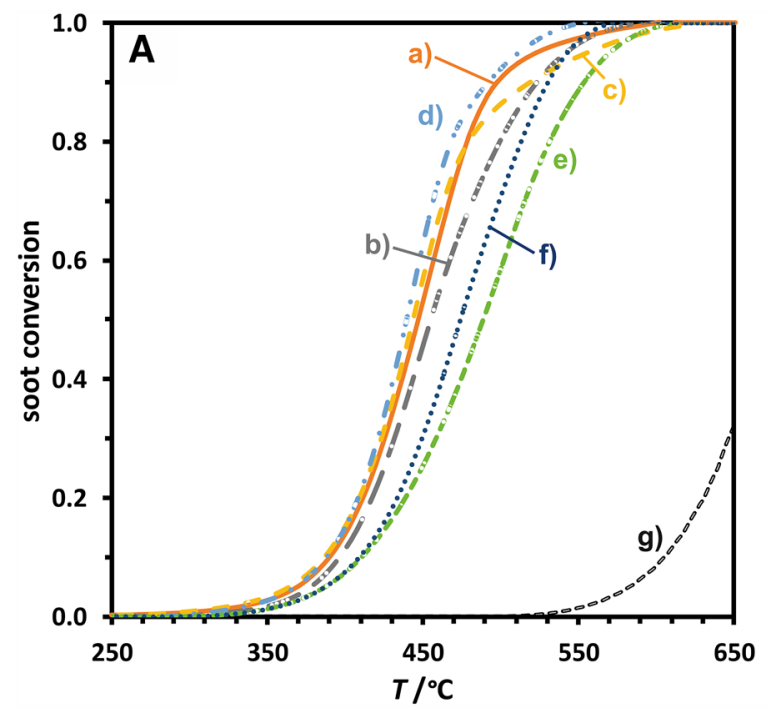

Fig. 1 Conversion of soot as a function of reaction temperature on birnessite (A) and cryptomelane (B)-type catalysts. bir/cryp_ref $(a)$, bir/cryp_mod $(b)$, bir/cryp_5Co $(c)$, bir/cryp_12Co $(d)$, bir/

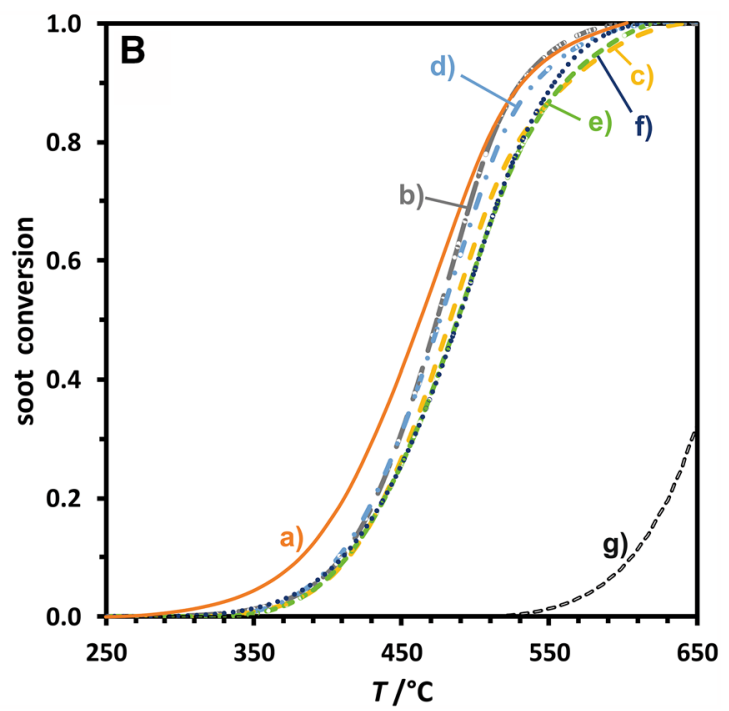

cryp_5Co_imp $(e)$, bir/cryp_12Co_imp $(f)$, non-catalytic reaction $(g)$. Soot/catalyst ratio equal $1 / 10$, loose contact mode

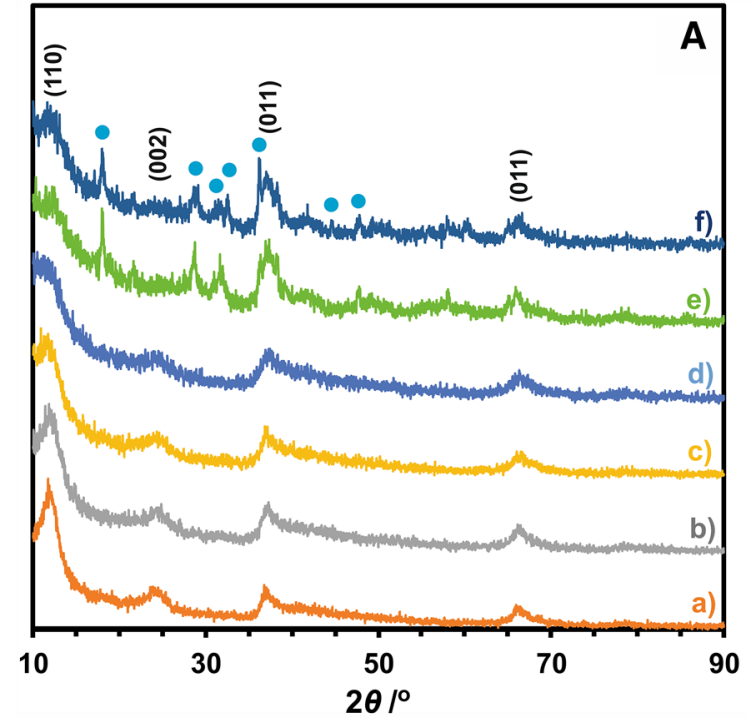

Fig. 2 Diffraction patterns of birenssite (A) and cryptomelane (B)type catalysts. bir/cryp_ref $(a)$, bir/cryp_mod $(b)$, bir/cryp_5Co $(c)$, bir/cryp_12Co $(d)$, bir/cryp_5Co_imp $(e)$, bir/cryp_12Co_imp

units of these two phases are $\mathrm{MnO}_{6}$ octahedra, from which the tunnels and layers are built. The effective ionic radii in octahedral coordinations of $\mathrm{Mn}^{3+}(58 \mathrm{pm}$ in low spin surface complexes and $64.5 \mathrm{pm}$ in high spin surface complexes) and $\mathrm{Co}^{3+}(54.5 \mathrm{pm}$ in low spin surface complexes and $61 \mathrm{pm}$ in high spin surface complexes), as well as those of $\mathrm{Mn}^{4+}$ (53 pm in low spin surface complexes) and $\mathrm{Co}^{4+}(53 \mathrm{pm}$ in high spin surface complexes) [32] are practically the same, so a replacement of manganese centers by cobalt ions in

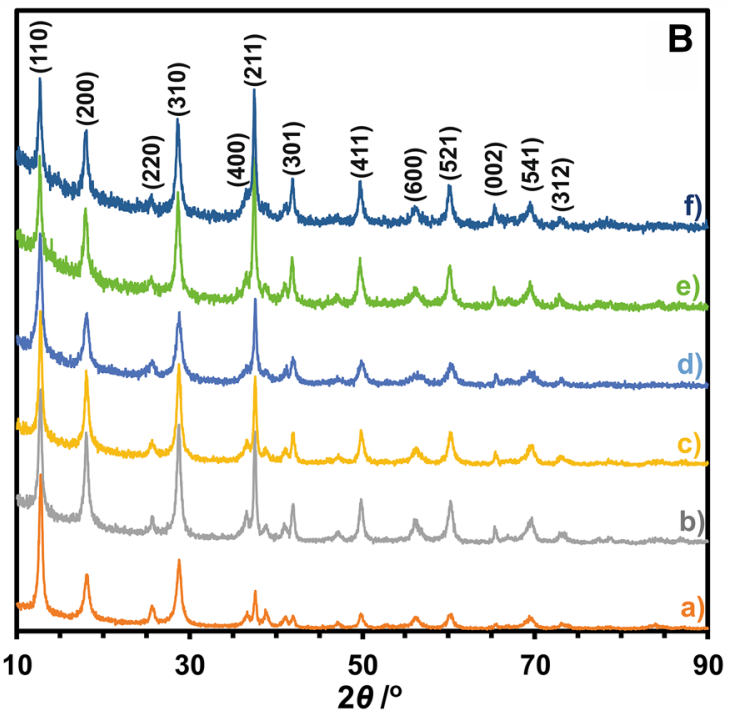

(f). The characteristic reflections attributed to $\mathrm{Mn}_{2.42} \mathrm{Co}_{0.58} \mathrm{O}_{2}$ were marked with full blue circles

cationic positions of cryptomelane and birnessite should not lead to any substantial geometry changes and thus cannot be distinctly manifested in the recorded diffraction patterns.

Another possible explanation of the observed weak catalytic effect of the doping of both types of catalysts doped with cobalt might be a loss of the dopant during preparation procedures, it is however almost improbable, regarding the results of XRF analysis (discussed in detail below), confirming the presence of cobalt in all investigated samples. A lack 
of Co-containing nanocrystallites due to a high dispersion of cobalt species on the surfaces of both cryptomelane and birnessite catalysts cannot be a priori excluded basing on our XRD results. Such a case is however rather weakly probable, taking into account the weak activity boosting effect observed after the introduction of cobalt into the Mn-based catalyst structures.

The concentrations of cobalt in the bulk of the investigated samples were determined by X-ray fluorescence and summarized in Table 2. The obtained results showed that the amount of cobalt was very close to the nominal values in all analyzed cases. As it was stated earlier, this result excluded the hypothesis related to the cobalt loss during the preparative steps. Moreover, variations in potassium to manganese ratios can be observed in all cases of the investigated samples: the undoped birnessite exhibited a deficiency in potassium, while cobalt addition to the precursor mixture before hydrothermal treatment permitted a small excess of potassium. For cobalt-impregnated birnessite a huge deficiency (up to 50\%) of potassium was observed. In the case of cryptomelane, generally, the deficiency of potassium was observed but it was much lower than those observed for cobalt-impregnated birnessite.

The results obtained by Raman spectroscopy for both undoped and Co-doped cryptomelane and birnessite (Fig. 3) basically confirmed the results provided by XRD. Two broad bands at ca. $570 \mathrm{~cm}^{-1}$ and ca. $640 \mathrm{~cm}^{-1}$ distinctly predominated the RS spectra of birnessite but some weak peaks at ca. 270, 385 and $510 \mathrm{~cm}^{-1}$ can also be visible (Fig. 3A), as previously reported in literature $[12,15]$. Moreover, for birnessite impregnated with the cobalt solution (Fig. 3Ae-f), additional bands were observed at 180,530 and $625 \mathrm{~cm}^{-1}$.
They can be related to the presence of manganese-cobalt spinel [15], which is in agreement with the information inferred from diffraction patterns recorded for these samples. For the cryptomelane series (Fig. 3B) the set of characteristic bands was observed in the Raman spectra at $c a .185 \mathrm{~cm}^{-1}$ and $385 \mathrm{~cm}^{-1}$ (attributed to Mn-O-Mn bending vibrations within the $\mathrm{MnO}_{2}$ octahedral lattice), $575 \mathrm{~cm}^{-1}$ (displacement of oxygen anions neighboring to manganese cations along the direction of octahedral chains) and $635 \mathrm{~cm}^{-1}(\mathrm{Mn}-\mathrm{O}$ stretching modes within tetrahedral sites), which remains in agreement with previously published literature data [12, $15,33]$. Based on the analysis of Raman active vibrational modes, it can be confirmed, that neither cobalt presence nor its concentration did not significantly influence the structure of both cryptomelane and birnessite.

Attenuated Total Reflectance-Infrared spectra are shown in Fig. 4. For birnessite (Fig. 4A) mainly the broad band at ca. $3400 \mathrm{~cm}^{-1}$ attributed to stretching vibrations of interlayer hydrates [34] can be observed. What is characteristic of cobalt-impregnated samples, the intensity of this band was distinctly lower than that visible for the undoped birnessite and both bir_5Co and bir_12Co. This result agrees with previously reported structural data, as the formation of manganese-cobalt spinel must lead to a decrement in the amount of interlayer water. The spinel structure does not contain enough space for water so it must leave system. The peaks of low intensity, observed in the region $2840-3050 \mathrm{~cm}^{-1}$, can be correspondingly attributed to both asymmetric and symmetric stretching modes of $\mathrm{H}_{2} \mathrm{O}$ molecules located between birnessite layers [34]. Some adsorbed carbonate species were observed in the range $1150-1725 \mathrm{~cm}^{-1}$ [34], while below $800 \mathrm{~cm}^{-1}$ the peaks assigned to $\mathrm{Mn}-\mathrm{O}$
Table 2 Elemental composition of the investigated samples determined by XRF and their surface composition determined by XPS

\begin{tabular}{|c|c|c|c|c|}
\hline \multirow[t]{2}{*}{ Sample } & \multicolumn{2}{|l|}{ Bulk (by XRF) } & \multicolumn{2}{|l|}{ Surface (by XPS) } \\
\hline & True formula & $\begin{array}{l}\text { Cobalt concentra- } \\
\text { tion }(\mathrm{mol} \%)\end{array}$ & Surface composition & $\begin{array}{l}\text { Cobalt } \\
\text { concentration } \\
(\mathrm{mol} \%)\end{array}$ \\
\hline \multicolumn{5}{|l|}{ Birnessite } \\
\hline bir_ref & $\mathrm{K}_{0.88} \mathrm{Mn}_{4} \mathrm{O}_{8}$ & - & $\mathrm{K}_{1.08} \mathrm{Mn}_{4} \mathrm{O}_{11.57}$ & - \\
\hline bir_mod & $\mathrm{K}_{0.93} \mathrm{Mn}_{4} \mathrm{O}_{8}$ & - & $\mathrm{K}_{1.25} \mathrm{Mn}_{4} \mathrm{O}_{10.47}$ & - \\
\hline bir_5Co & $\mathrm{K}_{1.01} \mathrm{Mn}_{4} \mathrm{O}_{8}$ & 4.95 & $\mathrm{~K}_{1.24} \mathrm{Mn}_{4} \mathrm{O}_{10.19}$ & 0.3 \\
\hline bir_12Co & $\mathrm{K}_{1.08} \mathrm{Mn}_{4} \mathrm{O}_{8}$ & 13.12 & $\mathrm{~K}_{1.19} \mathrm{Mn}_{4} \mathrm{O}_{10.90}$ & 0.9 \\
\hline bir_5Co_imp & $\mathrm{K}_{0.62} \mathrm{Mn}_{4} \mathrm{O}_{8}$ & 5.13 & $\mathrm{~K}_{1.26} \mathrm{Mn}_{4} \mathrm{O}_{12.82}$ & 0.5 \\
\hline bir_12Co_imp & $\mathrm{K}_{0.52} \mathrm{Mn}_{4} \mathrm{O}_{8}$ & 10.69 & $\mathrm{~K}_{1.14} \mathrm{Mn}_{4} \mathrm{O}_{11.75}$ & 2.5 \\
\hline \multicolumn{5}{|l|}{ Cryptomelane } \\
\hline cryp_ref & $\mathrm{K}_{0.85} \mathrm{Mn}_{8} \mathrm{O}_{16}$ & - & $\mathrm{K}_{0.93} \mathrm{Mn}_{8} \mathrm{O}_{20.94}$ & - \\
\hline cryp_mod & $\mathrm{K}_{1.02} \mathrm{Mn}_{8} \mathrm{O}_{16}$ & - & $\mathrm{K}_{0.97} \mathrm{Mn}_{8} \mathrm{O}_{18.21}$ & - \\
\hline cryp_5Co & $\mathrm{K}_{0.94} \mathrm{Mn}_{8} \mathrm{O}_{16}$ & 4.48 & $\mathrm{~K}_{1.01} \mathrm{Mn}_{8} \mathrm{O}_{21.74}$ & 0.7 \\
\hline cryp_12Co & $\mathrm{K}_{1.00} \mathrm{Mn}_{8} \mathrm{O}_{16}$ & 11.02 & $\mathrm{~K}_{1.24} \mathrm{Mn}_{8} \mathrm{O}_{21.55}$ & 1.4 \\
\hline cryp_5Co_imp & $\mathrm{K}_{0.85} \mathrm{Mn}_{8} \mathrm{O}_{16}$ & 5.97 & $\mathrm{~K}_{1.43} \mathrm{Mn}_{8} \mathrm{O}_{21.89}$ & 1.2 \\
\hline cryp_12Co_imp & $\mathrm{K}_{0.88} \mathrm{Mn}_{8} \mathrm{O}_{16}$ & 11.76 & $\mathrm{~K}_{1.10} \mathrm{Mn}_{8} \mathrm{O}_{28.76}$ & 2.8 \\
\hline
\end{tabular}



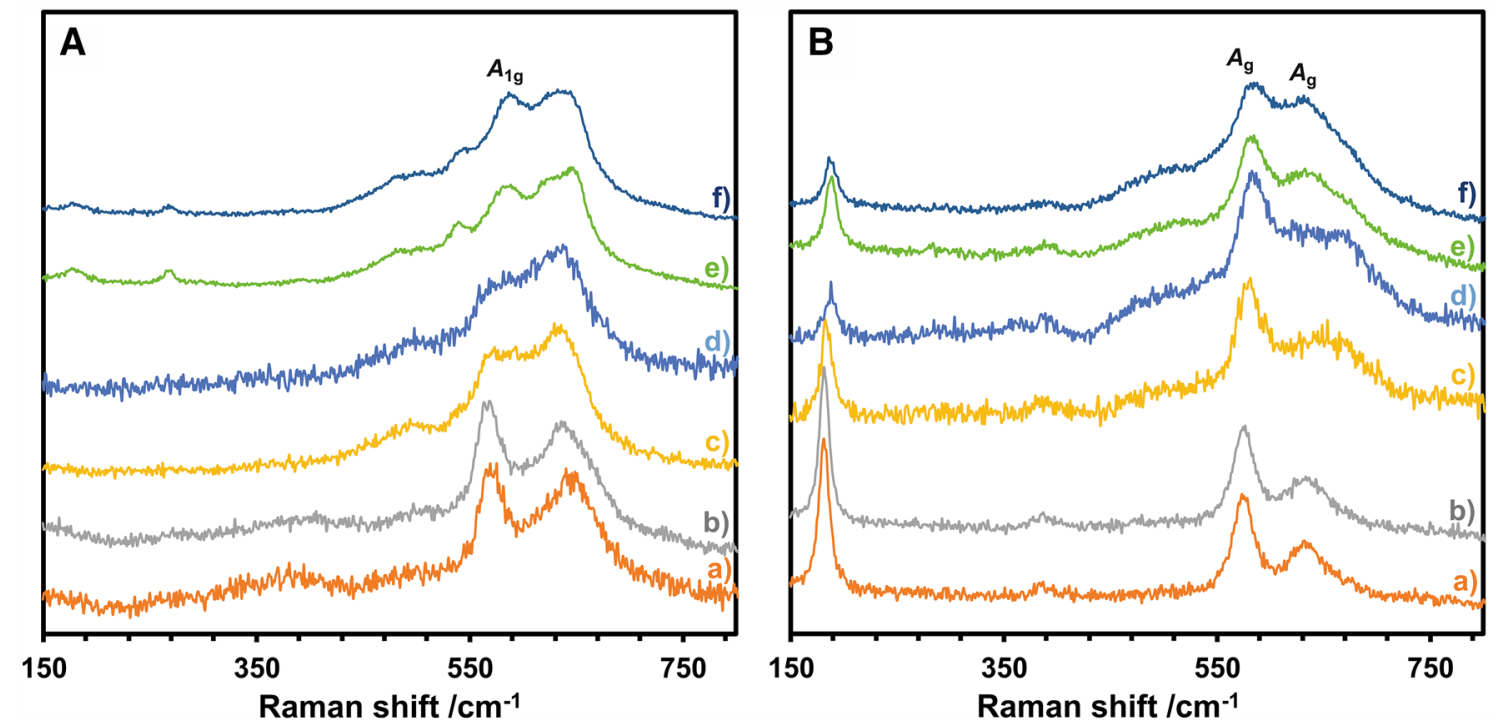

Fig. 3 Raman spectra of birenssite (A) and cryptomelane (B)-type catalysts. bir/cryp_ref (a), bir/cryp_mod (b), bir/cryp_5Co (c), bir/cryp_12Co $(d)$, bir/cryp_5Co_imp $(e)$, bir/cryp_12Co_imp $(f)$
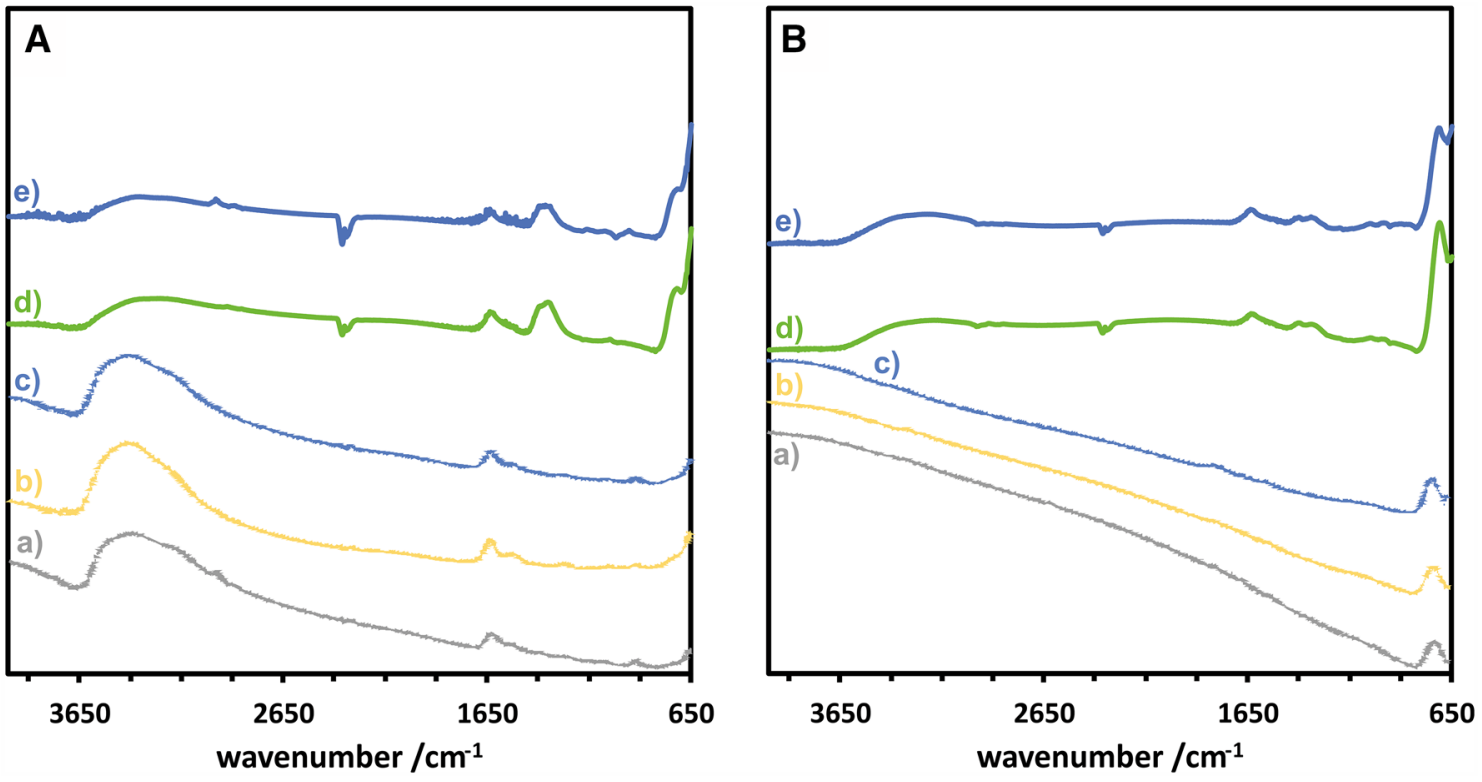

Fig. 4 ATR-IR spectra birenssite (A) and cryptomelane (B)-type catalysts. bir/cryp_mod (a), bir/cryp_5Co (b), bir/cryp_12Co (c), bir/ cryp_5Co_imp $(d)$, bir/cryp_12Co_imp $(e)$

lattice vibrations were found [34]. The bands at $c a .700$ and $1610 \mathrm{~cm}^{-1}$ visible in Fig. 4B can be ascribed to the vibrations of the $\mathrm{MnO}_{6}$ octahedral framework, characteristic of the cryptomelane structure [33]. Some adsorbed carbonate species gave rise to the bands observed in the range $1150-1725 \mathrm{~cm}^{-1}$ in the case of both cobalt-impregnated cryptomelane samples (Fig. 4Be-f) [34]. For cryp_5Co_imp and cryp_12Co_imp also a broad peak attributed to adsorbed water molecules at $c a .3400 \mathrm{~cm}^{-1}$ was clearly visible [34].
Basing on the obtained ATR-IR results, it can be stated, that cobalt-doping by addition of its precursor to reaction mixtures did not lead to any substantial changes in the surface structure, while impregnation clearly resulted in lowering the amount of interlayer water in the case of birnessite and in the appearance of water adsorbed on the surface or inside the channels in the case of cryptomelane. For impregnated cryptomelane (cryp_5Co_imp and cryp_12Co_imp) it can be stated based on our ATR-IR results that some cobalt 
species were stabilized on the surface (appearance of peaks attributed to carbon-containing species stabilized on $\mathrm{Co}$ sites) and thus the hypothesis assuming rather strong cobalt dispersion seemed to be confirmed. For both cryptomelane and birnessite samples, to which cobalt was introduced with precursor mixture before hydrothermal treatment, the stabilization of cobalt in highly dispersed surface nanocrystals can be excluded.

The presence of cobalt on the surface of the investigated catalysts was also investigated also in more depth by X-ray photoelectron spectroscopy. As it can be seen in Table 2, for all samples the determined cobalt concentrations were distinctly lower than for the nominal ones (from 4 to 16 times). It is also worthy to notice that the surface concentrations of cobalt were from 1.5 to 4 times higher for the impregnated samples than for the corresponding samples obtained by the addition of the cobalt precursor to the mixture before hydrothermal treatment. This result was expected, as the thermally-induced diffusion of cobalt ions into cryptomelane and birnessite lattices at $300{ }^{\circ} \mathrm{C}$ cannot be efficient. It may also suggest that the corresponding spinel structure was also, in a very limited extent, formed and stabilized on the surface, limiting catalytic activity of birnessite because of the lack of direct interaction between transition metal centers and potassium and fixed oxidation states of manganese centers. Due to relatively low intensity of the XPS signal, it was rather difficult to determine the exact speciation of cobalt but it can be assessed based on the corresponding peak positions to $\mathrm{Co}^{3+}$ centers in octahedral coordination [35]. Furthermore, as it can be seen in Fig. 5, the status of surface cobalt centers was similar in all analyzed cases. Moreover, an excess of both potassium and oxygen on the surface of birnessite were detected on a similar level. In the case of cryptomelane the excess of oxygen was confirmed for all samples, whereas the excess of potassium only for cobalt-doped samples. Cobalt presence did not influence the surface status of the other elements $(\mathrm{K}, \mathrm{Mn}, \mathrm{O})$ in the investigated samples and the obtained results were similar to those already reported elsewhere [24, 36].

Taking into account all results reported above, it can be concluded that cobalt was located mainly within the bulk of all investigated samples, which partially explains the observed lack of any substantial influence of cobalt doping on the catalytic activity of both cryptomelane and birnessite in soot combustion. Another possible structural factor contributing into this effect is the absence of direct interaction between transition metal centers and potassium, which cannot be easily stabilized within the formed spinel structures.

\subsection{Structural Properties of Reference Samples}

For better understanding of the results reported above and, in particular, to determine the status of cobalt within the birnessite and cryptomelane structures as well as its thermal evolution, single and binary $\mathrm{CoO}_{\mathrm{x}}-\mathrm{MnO}_{\mathrm{x}}$ reference samples have been synthesized via coprecipitation and structurally characterized in detail. Diffraction patterns of the reference samples are shown in Fig. 6. A sample containing $100 \%$ of manganese and calcined at $430{ }^{\circ} \mathrm{C}$ (Fig. 6Aa) exhibited the structure of pyrolusite, $\beta-\mathrm{MnO}_{2}$ (PDF code 00-004-0591),
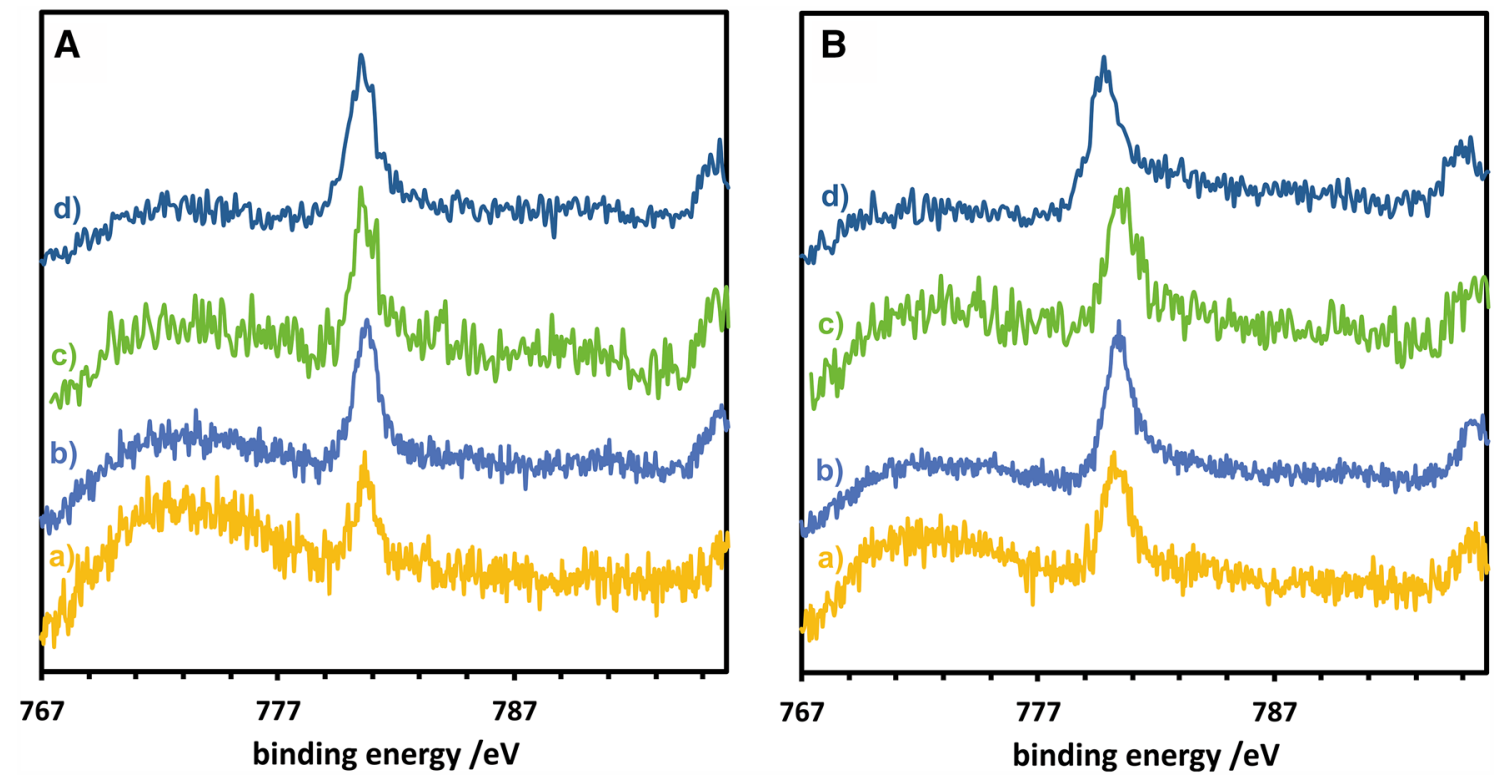

Fig. 5 XPS spectra of Co 2p region of cobalt-doped birnessite (A) and cryptomelane (B). bir/cryp_5Co (a), bir/cryp_12Co (b), bir/cryp_5Co_ $\operatorname{imp}(c)$, bir/cryp_12Co_imp $(d)$ 

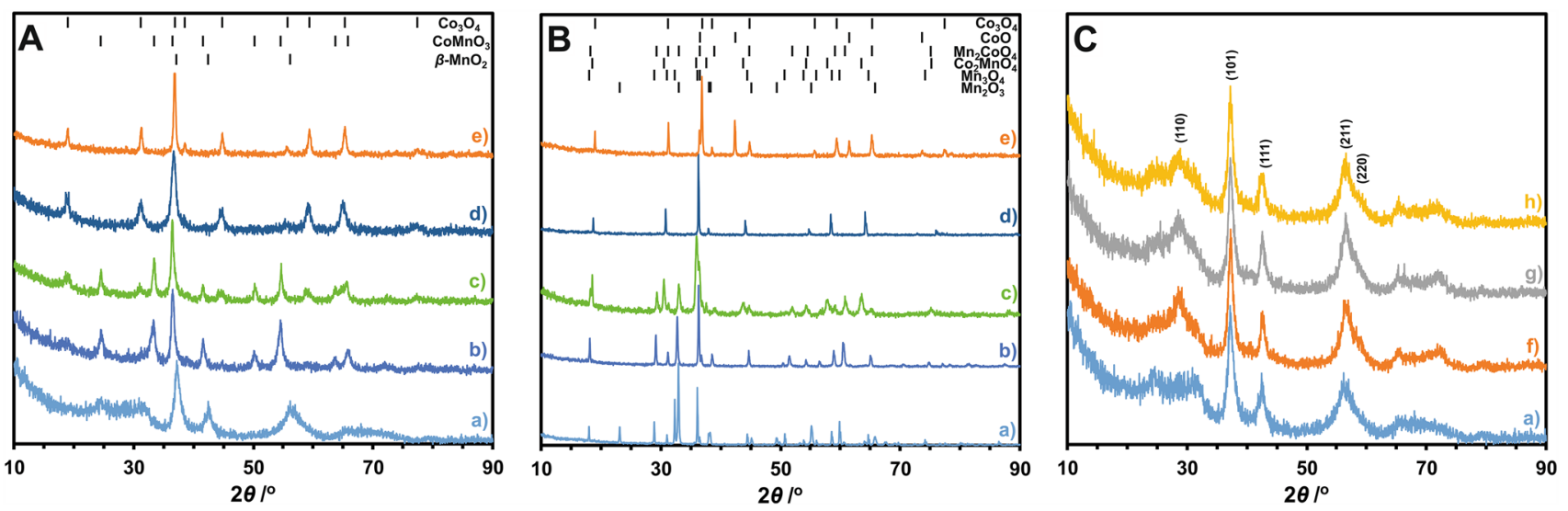

Fig. 6 Diffraction patterns of manganese-cobalt mixed oxides calcined at $430{ }^{\circ} \mathrm{C}(\mathbf{A})$ and at $980{ }^{\circ} \mathrm{C}(\mathbf{B})$ together with XRD patterns recorded for pyrolusite impregnated with cobalt precursor $(\mathbf{C})$.
100Mn-430/980 (a), 75Mn-430/980 (b), 50Mn-430/980 (c), 25Mn430/980 (d), 0Mn-430/980 (e), 0.5Co-Mn $(f), 1 \mathrm{Co}-\mathrm{Mn}(\mathrm{g}), 3 \mathrm{Co}-\mathrm{Mn}$ (h) while the presence of cobalt $(75 \% \mathrm{Mn}-25 \% \mathrm{Co}-\mathrm{Fig} .6 \mathrm{Ab})$ led to a formation of $\mathrm{CoMnO}_{3}$ (PDF code 03-065-3696) with a ilmenite $\mathrm{FeTiO}_{3}$ structure (space group $R 3$, trigonal system) [37]. Increasing the concentration of cobalt (Fig. 6Ac-f) led to the appearance of $\mathrm{Co}_{3} \mathrm{O}_{4}$ cobalt oxide of the spinel structure (PDF code 04-008-2376). For the sample $25 \mathrm{Mn}-430$ only the reflections characteristic of $\mathrm{Co}_{3} \mathrm{O}_{4}$ can be identified in the corresponding XRD pattern. Further thermal treatment of those samples up to $980{ }^{\circ} \mathrm{C}$ promoted distinct structural changes towards new complex oxide structures. Thermally-induced evolution resulted in structural conversion of pyrolusite into a mixture of $\mathrm{Mn}_{3} \mathrm{O}_{4}$ manganese spinel (PDF code 04-015-2577) and $\mathrm{Mn}_{2} \mathrm{O}_{3}$ manganese(III) oxide (PDF code 01-082-9910) (Fig. 6Ba). $\mathrm{CoMnO}_{3}$ was in turn converted into a mixed cobalt-manganese spinel with $\mathrm{Mn}_{2.42} \mathrm{Co}_{0.58} \mathrm{O}_{4}$ composition (Fig. 6Bb). This phase was observed as admixture in both impregnated birnessite samples bir_5Co_imp and bir_12Co_imp. The sample 50Mn-980 (Fig. 6Bc) was an equimolar mixture of two manganese-cobalt complex oxides, both exhibiting spinel structures- $\mathrm{Mn}_{2} \mathrm{CoO}_{4}$ (PDF code 04-005-7645) and $\mathrm{Co}_{2} \mathrm{MnO}_{4}$ (PDF code 01-084-4044). For 25Mn-980 (Fig. 6Bd), except of sintering and the related grain size increase (significant decrement in the widths of XRD reflections), no structural changes caused by thermal treatment can be observed. The sample $0 \mathrm{Mn}-980$ being a single cobalt spinel (Fig. 6Bf) was partially reduced during heating up to $980{ }^{\circ} \mathrm{C}$ and the reflections attributed to cobalt(II) oxide CoO (PDF code 01-076-3832) appeared in the XRD pattern of 0Mn-980 (one-third of the sample by a semiquantitative analysis of the reflections intensities). All structure modifications described above can be considered as the border limit high-temperature structures, clearly illustrating the strong tendency of cobalt additives to be stabilized within the bulk of the investigated catalysts, remaining practically inaccessible for the reactants of total soot oxidation. On the other hand, the status of cobalt in all compounds identified for thermally-treated reference samples described above is related with fixed oxidation states, required by the stoichiometry of the new phases. In such a case a switch between various oxidation states facilitating the activation of substrates of the catalytic reaction occurring on the catalyst surface is rather hardly possible. A series of $\beta-\mathrm{MnO}_{2}$ samples impregnated with aqueous solutions of cobalt precursor of adequate concentrations (Fig. 6C) did not exhibit any additional features in their XRD patterns in comparison to the parent pyrolusite sample.

The quality of Raman spectrum of pyrolusite (Fig. 7Aa) was quite poor due to rather weak crystallinity of the $100 \mathrm{Mn}$ sample calcined at $430{ }^{\circ} \mathrm{C}$, however the characteristic peaks at ca. $165 \mathrm{~cm}^{-1}\left(B_{1 \mathrm{~g}}\right), 575 \mathrm{~cm}^{-1}\left(E_{\mathrm{g}}\right), 645 \mathrm{~cm}^{-1}\left(A_{1 \mathrm{~g}}\right)$ and $750 \mathrm{~cm}^{-1}\left(B_{2 \mathrm{~g}}\right)$ can be distinguished and attributed to the vibrations typical of $\beta-\mathrm{MnO}_{2}$ [38]. The Raman spectrum of $\mathrm{CoMnO}_{3}$ (Fig. 7Ab) exhibited the peaks at $c a .170 \mathrm{~cm}^{-1}$, $265 \mathrm{~cm}^{-1}, 390 \mathrm{~cm}^{-1}, 480 \mathrm{~cm}^{-1}$ and $615 \mathrm{~cm}^{-1}$, resembling the Raman spectra of $\mathrm{CoMnO}_{3}$ sample reported elsewhere [39]. For the 50Mn-430 sample beside the peaks attributed to $\mathrm{CoMnO}_{3}$ (at ca. $170 \mathrm{~cm}^{-1}, 265 \mathrm{~cm}^{-1}, 390 \mathrm{~cm}^{-1}$, $480 \mathrm{~cm}^{-1}$ and $615 \mathrm{~cm}^{-1}$ ), also the peaks assigned to $\mathrm{Co}_{3} \mathrm{O}_{4}$ spinel appeared in the recorded spectrum at $\mathrm{ca} .195 \mathrm{~cm}^{-1}$ $\left(E_{\mathrm{g}}\right), 475 \mathrm{~cm}^{-1}\left(F_{2 \mathrm{~g}}\right), 525 \mathrm{~cm}^{-1}\left(F_{2 \mathrm{~g}}\right), 620 \mathrm{~cm}^{-1}\left(F_{2 \mathrm{~g}}\right)$ and $670 \mathrm{~cm}^{-1}\left(A_{1 \mathrm{~g}}\right)$, which also remains in agreement with the literature data [15] (Fig. 7Ac). Increase of cobalt content in binary samples resulted in the presence of the peaks attributed to the cobalt spinel only (Fig. 7Ad-e). For the samples calcined at $980{ }^{\circ} \mathrm{C}$ the structural transition from $\mathrm{Mn}_{3} \mathrm{O}_{4}$ to $\mathrm{Co}_{3} \mathrm{O}_{4}$, accompanying composition changes is clearly visible in Fig. 7B, reflecting not only thermal but also compositional changes. The presence of cobalt manifested itself in the corresponding Raman spectrum in the appearance of 

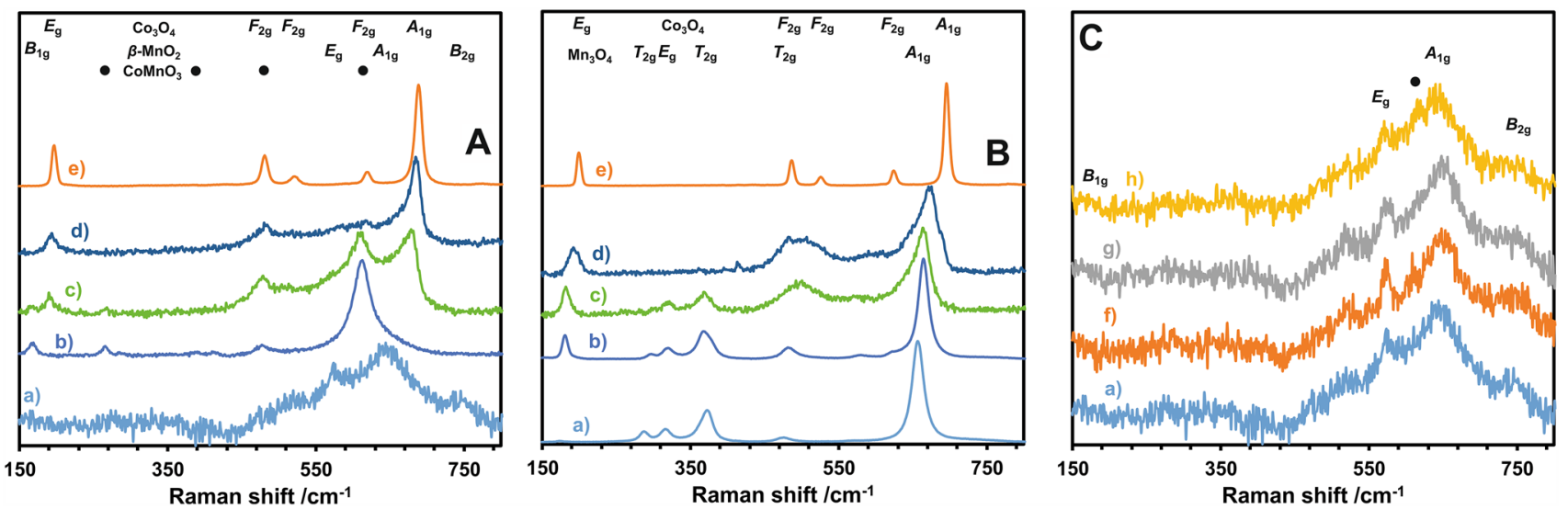

Fig. 7 Raman spectra of manganese-cobalt mixed oxides calcined at $430{ }^{\circ} \mathrm{C}$ (A) and at $980{ }^{\circ} \mathrm{C}$ (B) together with with Raman spectra recorded for pyrolusite impregnated with cobalt precursor $(\mathbf{C})$.

two peaks at $c a .180 \mathrm{~cm}^{-1}$ and $580 \mathrm{~cm}^{-1}$ and in their shift to $195 \mathrm{~cm}^{-1}$ and $620 \mathrm{~cm}^{-1}$, respectively, under the influence of the replacement of manganese by cobalt in the spinel structure. The intensity of peaks at $c a$. 290, 310 and $375 \mathrm{~cm}^{-1}$ attributed to $\mathrm{Mn}_{3} \mathrm{O}_{4}$ lowered with the decrement of manganese content and their positions shifted slightly as a result of manganese replacement by cobalt in the spinel structure. Moreover, the most intense peak visible in the Raman spectrum was shifted from $655 \mathrm{~cm}^{-1}$ (for $100 \mathrm{Mn}$ 980 ) to $670 \mathrm{~cm}^{-1}$ (for 0Mn-980). The observed effects can be explained by the progressive substitution of both $\mathrm{Mn}^{2+}$ and $\mathrm{Mn}^{3+}$ by $\mathrm{Co}^{2+}$ and $\mathrm{Co}^{3+}$, respectively in both tetrahedral (A) and octahedral (B) positions, respectively, as it can be seen for 50Mn-980 sample with equimolar composition of $\mathrm{Mn}_{2} \mathrm{CoO}_{4}$ and $\mathrm{Co}_{2} \mathrm{MnO}_{4}$ spinels. In Fig. $7 \mathrm{C}$ the Raman spectra of pyrolusite impregnated with cobalt(II) nitrate(V) aqueous solution are shown. No dramatic changes can be observed comparing to the parent sample but an additional peak at $c a .620 \mathrm{~cm}^{-1}$ visible in the spectrum for the sample $3 \mathrm{Co}-\mathrm{Mn}$ can be assigned to one of vibrations of $\mathrm{CoMnO}_{3}$ (Fig. 7Ch). This feature may be regarded as further evidence that cobalt and manganese tend to form mixed oxides in relatively low temperatures (i.e. $430{ }^{\circ} \mathrm{C}$ ), occurring also at the doping of birnessite and cryptomelane with cobalt additives.

\section{Conclusions}

Summarizing the obtained structural and functional results it can be stated, that due to a formation of the corresponding substitutional solid solutions, doping of birnessite and cryptomelane with cobalt (introduced by both addition of a cobalt precursor to the reactant mixture and by impregnation of the parent samples with a cobalt nitrate solution) did not induce any substantial changes in the
100Mn-430/980 (a), 75Mn-430/980 (b), 50Mn-430/980 (c), 25Mn430/980 (d), 0Mn-430/980 (e), 0.5Co-Mn $(f), 1 \mathrm{Co}-\mathrm{Mn}(g), 3 \mathrm{Co}-\mathrm{Mn}$ (h)

three-dimensional geometry of their lattices. Contrary to this, impregnation of birnessite with cobalt precursors facilitated the formation of an admixture of manganesecobalt binary oxide. Elemental analysis confirmed the presence of cobalt in the amounts close to the nominal and the amounts of potassium varied from 0.52 to 1.08 , while the nominal value was 1 . The deviation in potassium content can be a consequence of its segregation and loss during the synthesis. This effect can be considered as important for the catalytic properties of the investigated systems. The relatively low surface concentration of cobalt was confirmed by XPS for the doped cryptomelane and birnessite samples, confirming the stabilization of the dopant within $\mathrm{KMn}_{4} \mathrm{O}_{8}$ and $\mathrm{KMn}_{8} \mathrm{O}_{16}$ bulks of limited accessibility to the reactants of soot combustion. Impregnation of the parent Mn-based samples with cobalt(II) nitrate $(\mathrm{V})$ solution seemed to be more efficient for stabilization of cobalt surface species than the addition of this precursor to the reactant mixture before hydrothermal treatment. In depth structural studies on thermal evolution of the reference samples confirmed the strong tendency of cobalt to be stabilized within both birnessite and cryptomelane manganese oxide structures. These facts together with potassium segregation and loss can be decisive for the confirmed unexpectedly weak effect of cobalt additives on catalytic activity of both cryptomelane and birnessite samples in soot combustion and the reported results may be used as practical guidelines for further optimization of both surface and structural modifications of potassiumcontaining, Mn-based systems towards their higher performance in such catalytic applications.

Acknowledgements The research was financed by Jagiellonian University Faculty of Chemistry Grants No. K/DSC/004574 and K/ ZDS/007801. Tomasz Jakubek received funding for the preparation 
of his doctoral dissertation from the Polish National Science Center under the doctoral scholarship funding program based on the decision number UMO-2017/24/T/ST5/00413.

Open Access This article is distributed under the terms of the Creative Commons Attribution 4.0 International License (http://creativeco mmons.org/licenses/by/4.0/), which permits unrestricted use, distribution, and reproduction in any medium, provided you give appropriate credit to the original author(s) and the source, provide a link to the Creative Commons license, and indicate if changes were made.

\section{References}

1. Johnson $\mathrm{T}$ (2016) Vehicular emissions in review. SAE Int $\mathrm{J}$ Engines. https://doi.org/10.4271/2016-01-0919

2. Guan B, Zhan R, Lin H, Huang Z (2015) Review of the state-ofthe-art of exhaust particulate filter technology in internal combustion engines. J Environ Manage 154:225-258. https://doi. org/10.1016/j.jenvman.2015.02.027

3. Fino D, Bensaid S, Piumetti M, Russo N (2016) A review on the catalytic combustion of soot in diesel particulate filters for automotive applications: from powder catalysts to structured reactors. Appl Catal A Gen 509:75-96. https://doi.org/10.1016/j.apcat a.2015.10.016

4. Hernández-Giménez AM, Castelló DL, Bueno-López A (2014) Diesel soot combustion catalysts: review of active phases. Chem Pap 68:1154-1168. https://doi.org/10.2478/s11696-013-0469-7

5. Gálvez ME, Ascaso S, Stelmachowski P, Legutko P, Kotarba A, Moliner R, Lázaro MJ (2014) Influence of the surface potassium species in $\mathrm{Fe}-\mathrm{K} / \mathrm{Al}_{2} \mathrm{O}_{3}$ catalysts on the soot oxidation activity in the presence of $\mathrm{NO}_{\mathrm{x}}$. Appl Catal B Environ 152-153:88-98. https ://doi.org/10.1016/j.apcatb.2014.01.041

6. Legutko P, Kaspera W, Jakubek T, Stelmachowski P, Kotarba A (2013) Influence of potassium and NO addition on catalytic activity in soot combustion and surface properties of iron and manganese spinels. Top Catal 56:745-749. https://doi.org/10.1007/s1124 4-013-0026-1

7. Liu T, Li Q, Xin Y, Zhang Z, Tang X, Zheng L, Gao PX (2018) Quasi free K cations confined in hollandite-type tunnels for catalytic solid (catalyst)-solid (reactant) oxidation reactions. Appl Catal B Environ 232:108-116. https://doi.org/10.1016/j.apcat b.2018.03.049

8. Bueno-López A (2014) Diesel soot combustion ceria catalysts. Appl Catal B Environ 146:1-11. https://doi.org/10.1016/j.apcat b.2013.02.033

9. Atribak I, Bueno-López A, García-García A, Navarro P, Frías D, Montes M (2010) Catalytic activity for soot combustion of birnessite and cryptomelane. Appl Catal B Environ 93:267-273. https:// doi.org/10.1016/j.apcatb.2009.09.038

10. Li Q, Wang X, Chen H, Xin Y, Tian G, Lu C, Zhang Z, Zheng L, Zheng L (2016) K-supported catalysts for diesel soot combustion: making a balance between activity and stability. Catal Today 264:171-179. https://doi.org/10.1016/j.cattod.2015.07.036

11. Legutko P, Stelmachowski P, Trębala M, Sojka Z, Kotarba A (2013) Role of electronic factor in soot oxidation process over tunnelled and layered potassium iron oxide catalysts. Top Catal 56:489-492. https://doi.org/10.1007/s11244-013-0003-8

12. Jakubek T, Kaspera W, Legutko P, Stelmachowski P, Kotarba A (2016) How to efficiently promote transition metal oxides by alkali towards catalytic soot oxidation. Top Catal 59:1083-1089. https ://doi.org/10.1007/s11244-016-0595-x

13. Jakubek T, Kaspera W, Legutko P, Stelmachowski P, Kotarba A (2015) Surface versus bulk alkali promotion of cobalt-oxide catalyst in soot oxidation. Catal Commun 71:37-41. https://doi. org/10.1016/j.catcom.2015.08.014

14. Stelmachowski P, Legutko P, Jakubek T, Indyka P, Sojka Z, Holmlid L, Kotarba A (2015) Emission of highly excited electronic states of potassium from cryptomelane nanorods. Phys Chem Chem Phys 17:26289-26294. https://doi.org/10.1039/c5cp04108b

15. Legutko P, Jakubek T, Kaspera W, Stelmachowski P, Sojka Z, Kotarba A (2017) Strong enhancement of deSoot activity of transition metal oxides by alkali doping: additive effects of potassium and nitric oxide. Top Catal 60:162-170. https://doi. org/10.1007/s11244-016-0727-3

16. Stelmachowski P, Legutko P, Jakubek T, Kotarba A (2018) Phase evolution and electronic properties of cryptomelane nanorods. J Alloys Compd 767:592-599. https://doi. org/10.1016/j.jallcom.2018.07.147

17. Becerra M-E, Arias N-P, Giraldo O-H, López-Suárez F-E, Illán-Gómez M-J, Bueno-López A (2012) Alumina-supported manganese catalysts for soot combustion prepared by thermal decomposition of $\mathrm{KMnO}_{4}$. Catalysts 2:352-367. https://doi. org/10.3390/catal2030352

18. Legutko P, Jakubek T, Kaspera W, Stelmachowski P, Sojka Z, Kotarba A (2014) Soot oxidation over K-doped manganese and iron spinels-how potassium precursor nature and doping level change the catalyst activity. Catal Commun 43:34-37. https:// doi.org/10.1016/j.catcom.2013.08.021

19. Kaspera W, Indyka P, Sojka Z, Kotarba A (2018) Bridging the gap between the tight and loose contact for soot oxidation by vanadium doping of cryptomelane nanorods catalyst using $\mathrm{NO}_{2}$ as an oxygen carrier. Catal Sci Technol. 8:3183-3192. https:// doi.org/10.1039/c8cy00545a

20. Bieniasz W, Tr M, Sojka Z, Kotarba A (2010) Irreversible deactivation of styrene catalyst due to potassium loss-Development of antidote via mechanism pinning. Catal Today 154:224-228. https://doi.org/10.1016/j.cattod.2010.03.059

21. Kotarba A, Ro W (2007) Reverse effect of doping on stability of principal components of styrene. J Catal 247:238-244. https ://doi.org/10.1016/j.jcat.2007.02.009

22. Hu B, Chen C, Frueh SJ, Jin L, Joesten R, Suib SL (2010) Removal of aqueous phenol by adsorption and oxidation with doped hydrophobic cryptomelane-type manganese oxide (KOMS-2) nanofibers. J Phys Chem C 114:9835-9844. https:// doi.org/10.1021/jp100819a

23. Ma J, Wang C, He H (2017) Transition metal doped cryptomelane-type manganese oxide catalysts for ozone decomposition. Applied Catal B Environ 201:503-510. https://doi. org/10.1016/j.apcatb.2016.08.050

24. Pahalagedara LR, Dharmarathna S, King CK, Pahalagedara MN, Meng Y, Kuo C, Suib SL (2014) Microwave-assisted hydrothermal synthesis of $\alpha-\mathrm{MnO}_{2}$ : lattice expansion via rapid temperature ramping and framework substitution. J Phys Chem. https:// doi.org/10.1021/jp505306q

25. Yin H, Liu F, Feng X, Hu T, Zheng L, Qiu G, Koopal LK, Tan W (2013) Effects of Fe doping on the structures and properties of hexagonal birnessites - comparison with $\mathrm{Co}$ and Ni doping. Geochim Cosmochim Acta 117:1-15. https://doi.org/10.1016/j. gca.2013.04.020

26. Korotkov RF, Baranchikov AE, Boytsova OV, Ivanov VK (2015) Synthesis of nanocrystalline birnessite and cryptomelane by microwave hydrothermal treatment. Russ J Inorg Chem 60:1299-1303. https://doi.org/10.1134/S0036023615110108

27. Liu G, Chen L, Yu J, Feng N, Meng J, Fang F, Wang L, Wan H, Guan G (2018) Interphase strengthening birnessite $\mathrm{MnO}_{2}$ coating on three-dimensional $\mathrm{Ni}$ foam for soot removal. Appl Catal A Gen 568:157-167. https://doi.org/10.1016/j.apcat a.2018.10.003 
28. Stelmachowski P, Monteverde Videla AHA, Jakubek T, Kotarba A, Specchia S (2018) The Effect of Fe, Co, and Ni structural promotion of cryptomelane (KMn8O16) on the catalytic activity in oxygen evolution reaction. Electrocatalysis 9:762-769. https:// doi.org/10.1007/s12678-018-0488-9

29. Christensen JM, Grunwaldt JD, Jensen AD (2016) Importance of the oxygen bond strength for catalytic activity in soot oxidation. Appl Catal B Environ 188:235-244. https://doi.org/10.1016/j. apcatb.2016.01.068

30. Christensen JM, Grunwaldt JD, Jensen AD (2017) Effect of $\mathrm{NO}_{2}$ and water on the catalytic oxidation of soot. Appl Catal B Environ 205:182-188. https://doi.org/10.1016/j.apcatb.2016.12.024

31. Maniak G, Stelmachowski P, Zasada F, Piskorz W, Kotarba A, Sojka Z (2011) Guidelines for optimization of catalytic activity of $3 \mathrm{~d}$ transition metal oxide catalysts in $\mathrm{N}_{2} \mathrm{O}$ decomposition by potassium promotion. Catal Today 176:369-372. https://doi. org/10.1016/j.cattod.2010.11.043

32. Shannon BYRD (1976) Revised effective ionic radii and systematic studies of interatomie distances in Halides and Chaleogenides. Acta Crystalographica A32:751-767

33. Riad SSM, Mikhail MHS (2016) Preparation of nano-structured cryptomelane materials for catalytic oxidation reactions. J Nanostruct Chem 6:171-182. https://doi.org/10.1007/s4009 7-016-0192-3

34. Eren E, Gumus H, Eren B, Sarihan A, Eren E (2013) Surface acidity of H-birnessite: infrared spectroscopic study of formic acid decomposition surface acidity of H-birnessite: infrared spectroscopic study of formic acid decomposition. https://doi. org/10.1080/00387010.2012.666612
35. Tholkappiyan R, Vishista K (2015) Tuning the composition and magnetostructure of dysprosium iron garnets by Co-substitution: an XRD, FT-IR, XPS and VSM study. Appl Surf Sci 351:10161024. https://doi.org/10.1016/j.apsusc.2015.05.193

36. Yin H, Feng X, Qiu G, Tan W, Liu F (2011) Characterization of Co-doped birnessites and application for removal of lead and arsenite. J Hazard Mater 188:341-349. https://doi.org/10.1016/j. jhazmat.2011.01.129

37. Villars $\mathrm{P}$, Cenzual $\mathrm{K} \mathrm{CoMnO}_{3}\left(\mathrm{MnCoO}_{3} \mathrm{rt}\right)$ Crystal structure: datasheet from PAULING FILE multinaries edition-2012 in SpringerMaterials. https://materials.springer.com/isp/crystallog raphic/docs/sd_1821276

38. Gao T, Fjellvåg H, Norby $\mathrm{P}$ (2009) A comparison study on Raman scattering properties of $\alpha$ - and $\beta-\mathrm{MnO}_{2}$. Anal Chim Acta 648:235239. https://doi.org/10.1016/j.aca.2009.06.059

39. Feng N, Chen C, Meng J, Wu Y, Liu G, Wang L, Wan H, Guan G (2016) Facile synthesis of three-dimensionally ordered macroporous silicon-doped $\mathrm{La}_{0.8} \quad \mathrm{~K}_{0.2} \mathrm{CoO}_{3}$ perovskite catalysts for soot combustion. Catal Sci Technol 6:7718-7728. https://doi. org/10.1039/C6CY00677A

Publisher's Note Springer Nature remains neutral with regard to jurisdictional claims in published maps and institutional affiliations. 